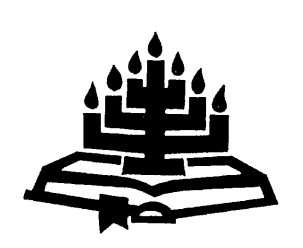

\title{
Women who win with words: Deliverance via persuasive communication
}

\author{
Robin G. Branch \\ School of Biblical Studies and Bible Languages \\ Potchefstroom University for CHE \\ POTCHEFSTROOM \\ E-mail: sbbrgb@puknet.puk.ac.za
}

Abstract

Women who win with words: Deliverance via persuasive communication

The Wise Woman of Abel Beth Maacah quells a rebellion (2 Sam. 20). Abigail, a beautiful and intelligent woman, rescues her household (1 Sam. 25). And the older sister of Moses, by tradition Miriam, saves her baby brother's life (Ex. 2). These two women and a girl represent political saviours who facilitate the deliverance of a city, community, and an individual via persuasive words. As winners with words, these orators contribute dynamically to the biblical text by providing an alternative way of deliverance, one enabling it to come through a means other than the sword. Via perceptive persuasion, they guide those with whom they interact toward choosing life and the common good. This article takes a cross-disciplinary approach to the biblical text by looking at the persuasive communication techniques these two women and a girl employ so successfully.

\section{Opsomming}

Vroue wat oorwin met woorde: redding deur oorredende kommunikasie

Die Wyse Vrou van Abel Bet Maäka onderdruk 'n opstand (2 Sam. 20). Abigajil, 'n pragtige, intelligente vrou, red haar huishouding (1 Sam. 25) en die ouer suster van Moses, volgens tradisie Miriam, red haar bababroer se lewe (Eks. 2). Hierdie twee vroue en 'n jong meisie verteenwoordig politieke verlossers, wat die redding van 'n stad, gemeenskap en 'n individu bewerkstellig deur hul oorredende woorde. As wenners met woorde dra hierdie sprekers dinamies by tot die Bybelse teks deur alternatiewe reddingsmoontlikhede voor te stel: 'n ander manier van redding as bloot deur middel van die swaard (of geweld). Deur middel van hul oorreding en insig lei hulle dié met wie hulle omgaan tot 'n keuse vir die behoud van lewe en die gemeenskaplike belang. Hierdie artikel gebruik 'n multi-dissiplinêre 
benadering tot die Bybelse tekste deur die kommunikasietegnieke wat hierdie twee vroue en 'n jong meisie suksesvol in die oorredingsproses aanwend, te ondersoek.

\section{Introduction}

The Wise Woman of Abel Beth Maacah1 turns the tables on Joab (2 Sam. 20). Abigail tames David, a hotheaded hero (1 Sam. 25), and the older sister of Moses, by tradition Miriam, guides a princess of Egypt towards motherhood (Ex. 2). These three - two women and a little girl represent political saviours who facilitate the deliverance of a city, community, and an individual via persuasive words. Armed only with their wits, they exhibit marked personal courage when faced with a crisis involving (apparently) superior forces.

Strategically using every means at their disposal - whether wisdom, audacity, winsomeness, vulnerability, verbosity, youth, or outright sex appeal - these women confront leaders, waylay armies, question established authority, and stave off unnecessary bloodshed. In the biblical stories in which these women appear, 2 they listen intently, ask clarifying questions, and present reasonable, on-the-spot solutions. In short, they persuade.

As political saviours whose weapons are words, the three judge between the righteous and unrighteous. They make life-and-death decisions and participate in their implementation. They seek to preserve life. Via keen rhetoric and quick thinking, Miriam delivers the baby Moses from death, Abigail saves her household from David's wrath, and the Wise Woman of Abel Beth Maacah quells a rebellion. All three women prove to be pivotal in Israel's history.

As winners with words, these orators contribute dynamically to the biblical text by providing an alternative model of deliverance, one enabling it to come through a means other than the sword. Via

Throughout this article, the Wise Woman of Abel Beth Maacah is referred to in capital letters. The author acknowledges that the English version of the biblical text keeps the lower case form. However, the phrase may well have been a title, something like the President of the United States in modern parlance.

2 This article takes a standard literary approach to the biblical text. Four literary devices in a narrative include the scene, an event that happens in a particular place and time and usually has only two speaking characters; the point of view, which includes a number of scenes that make up the plot; dialogue, a narrative tool telling the readers and hearers about a character; and rhetorical devices like repetition, inclusion, and chiasm (Kaiser \& Silva, 1994:71-76). J. Lostracco and G. Wilkerson (1998) break down a short story into the following elements in their book, Analyzing Short Stories: central idea, characterization, conflict, point of view, setting, tone, language, symbol and irony. 
perceptive persuasion, they guide those with whom they interact toward choosing life and the common good. This article examines these three persuasive political saviours and looks at the insights their stories provide for today.

\section{Four persuasive communication techniques}

These three biblical characters, employ what scholars now call persuasive communication. While several models of persuasive communication exist, R. Eales-White, a British communication specialist, provides one that works well for these stories in the biblical text. In his book, The Power of Persuasion: Improving Your Performance and Leadership Skills, he (Eales-White, 1997:5) lists four persuasive approaches: logic, incentives, empathy, and group.

\section{- Logic}

Briefly by way of definition, the person employing the logic persuasive approach uses facts and opinions and makes reasonable, logical connections between the two (Eales-White, 1997:35). The person using this system expects reason to prevail; in today's world, the educational system so successful in the developed world stresses logic and puts less stress on creativity and feelings (Eales-White, 1997:34-35). Logic uses knowledge, and uses it almost as a hammer as is seen with the Wise Woman of Abel Beth Maacah. She knocks Joab flat with this technique, logical persuasion.

\section{- Incentives}

The second persuasive approach, incentives, offers payment, motive, or some kind of provocation in order to bring about a desired and hoped for response (Eales-White, 1997:39). This persuasive approach looks at both means and ends. As a goal-oriented approach, it seeks to persuade someone else to behave in such a way as meets the personal agenda of the one speaking. The person using an incentives approach, often a manager in charge of people, also sets goals or objectives and expects them to be met. The one being persuaded believes in the goals set by the persuader and incorporates them (see Eales-White, 1997:39). The child Miriam employs this incentives technique.

\section{- Empathy}

Miriam also employs empathy, Eales-White's third persuasive technique. Via empathy, one person understands another's personality and experiences. Empathy enables two people to form a bond (see EalesWhite, 1997:42-43). 


\section{- Group tactics and a shared vision}

Eales-White calls the fourth and last persuasive technique group. He (Eales-White, 1997:45) outlines this technique as a grouping of shared concepts, ideas, dreams, and visions. A shared vision lies outside an individual or individuals and the sometimes competing visions that make up that individual or make up a community. The shared vision may not be openly articulated at first; it may reside on a subconscious level. So the persuader skilled in group tactics defines this vision, harnesses it, and implements it. Again this persuader senses and taps into the intrinsic needs of the person or persons in the group (Eales-White, 1997:45). Abigail uses this technique most successfully with David.

As will be seen in the discussion that follows, Miriam, Abigail, and the Wise Woman of Abel Beth Maacah, while strongest in the persuasion category mentioned, freely employ what works for them from other models as well. In this way they show their flexibility and femininity. This article's organizational order for dealing with the three characters and their stories is as follows: rabbinic sayings, a bit of history, the predicament the character finds herself in, and the persuasion techniques she uses. The article discusses each character in the order she appears in the biblical text.

\section{Miriam}

Miriam appears first in the Bible. The biblical text calls her a prophetess (Ex. 15:20) but gives no record of her prophecies. 3 The rabbis fill in this omission with a story about her, and this story helps explain the peculiar wording of Exodus 2:1-2a: "Now a man of the house of Levi married a Levite woman, and she became pregnant and gave birth to a son." 4 The biblical text progresses first to show that this baby son had an older sister and later introduces an older brother (Ex. 4:14; 7:7); these siblings were six and three years older respectively at the time of the baby's birth (Kramer, 2000:107). The problem is that these older siblings appear to be legitimate offspring from the same parents. The rabbis solve this problem by saying that Amram divorced Jochebed when they heard of Pharaoh's edict to the Hebrew midwives to kill the male Hebrew babies

3 The rabbis say there are seven prophetesses: Sarah, Deborah, Miriam, Hannah, Abigail, Huldah, and Esther (Babylonian Talmud, Megillah 14a). Three of these Deborah, Miriam, and Huldah - are called prophetesses in the biblical text; the biblical text also lists Noadiah, the false prophetess who tried to terrorize Nehemiah (Neh. $6: 14)$, as a prophetess, but she is not given credit by the rabbis. Sarah, Hannah, Abigail, and Esther are called prophetesses because their words, the rabbis say, are prophetic.

Although the biblical text shows Moses as the dominant character in the Pentateuch, it gives Miriam equal footing with her brothers elsewhere. In Micah 6:4, the Lord, speaking through the prophet, says, "I sent Moses to lead you, also Aaron and Miriam."

4 The scriptures in this article come from the New International Version of the Bible. 
(Ex. 1:15-19).5 Amram thought it better to divorce Jochebed than to sire children by her and see them exterminated. Others in the Israelite community followed his lead, likewise divorcing their wives. The young daughter of Amram and Jochobed, Miriam, rebukes her parents, especially her father, for cowardice. She tells them to marry each other again. She prophesies that the son born of their re-union will redeem Israel (see Exodus Rabbah. 1:17; Sotah. 12a; Pes. R. 43:4) (Kramer, 2000:107-108).

The biblical text opens with a family catastrophe and national predicament. 6 The beautiful son of Amram and Jochebed is under Pharaoh's death sentence because he is an Israelite (Ex. 1:22). ${ }^{7}$ The baby's mother hides the baby for three months. 8 Then she makes a papyrus basket for him and coats it with tar and pitch. The Hebrew word translated basket in the NIV is ark; it immediately connotes the other ark of deliverance that saved Noah and his family from the flood.9 This textual hint heralds an upcoming, mighty deliverance. They determine when and where to throw the baby. 10 The ark carrying its baby cargo sets off down the Nile.11

5 Rabbinic tradition also asserts that Jochebed and Miriam were the two Hebrew midwives, Shiphrah and Puah respectively (Ex. 1:15) (see Rappoport, 1966: vol. 2, 205).

$6 \quad$ The story of the birth and childhood deliverance of Moses, one of the most well-known and well-beloved stories in the biblical text, contains suspense, a battle between good and evil, unequal forces, chance, irony, whimsy, human initiative, and unequal forces. Pharaoh's edict is one of many in the biblical text in which the annihilation of the Jews is threatened and attempted.

7 The same word used to describe the baby Moses - good (tov) - is used to described God's various actions in creation (Fretheim, 1991:38).

8 The age of the siblings raises questions. According to the rabbis, the baby was born at six months, something that enabled Jochebed to elude detection of her pregnancy by onlookers and therefore to keep the baby in safety longer. Miriam's age also presents textual difficulties. The Hebrew text uses the word almah for the sister, a word traditionally used for a young woman of marriageable age as in Isaiah 7:14 (Hyatt, 1971: 64).

9 Although the Hebrew word for basket is tebah, it is used elsewhere only of Noah's ark (Gen. 6:14 ff) (Hyatt, 1971:63), and is not to be confused with the ark of the covenant. Durham (1987:16) sees the ark not as a cruel means of exposure but as a lovingly made means of salvation; furthermore, he sees the actions of the mother and sister as those of keeping careful watch from a distance.

10 The situation involves both an ethic of defenceless resistance and an action of creative disobedience (see Fretheim, 1991:32) (italics his).

11 Calvin (1852:40) believes the baby's parents are woefully timid, an action he finds almost inexcusable, for "they almost abandon the child, in order to escape from 
The text seems to be recounting the baby's last moments before drowning or execution. 12 Miriam watches what will happen. ${ }^{13}$ Notice the three calculations involved: First, the ark embarks from a relatively safe area, an area free from crocodiles, because the Egyptian princess, the daughter of Pharaoh, comes there to bathe. The water apparently flows fairly quickly and therefore provides good bathing; the force, however, is not great. Second, the baby's feeding schedule and the princess' bathing time coincide. The baby cries on cue!14 Third, the mother and sister gamble on the noble, courageous character of the princess.

Scholars differ on whether or not Miriam's interaction with the princess of Egypt is planned or spontaneous. 15 I opt for a combination of both, mainly because the biblical text gives ample evidence of two well-known facts: first, servants observe their masters, know how to please them, and manipulate situations to their own advantage;16 second, God's sovereignty recurs as a theme throughout the narrative text. Arguably,

danger". But Calvin's pastor's heart becomes visible when he cautions his readers against judging the parents too harshly. He (Calvin, 1852:41) notes that they must have suffered "terrible agonies" and "bitter grief" over the proposed fate of their child.

12 Apparently there are at least 32 myths and legends from the Ancient Near East that can be loosely grouped into a literary motif detailing the adventures of an exposed and abandoned child (Hyatt, 1971:62).

13 Perhaps the mother urged Miriam, because of her young age, to stand watch over the ark because as a child, Miriam probably would be exempt from danger. Calvin (1852: 42), however, chastises the parents for their neglect of duty. Yet their action of having Miriam stand watch proves they retained some hope for the boy's life, Calvin (1952:43) concedes.

Childs (1974:18) considers the role of the sister in the story, which begins in verse 4 , as "certainly one of the most delightful features in the narrative".

14 Durham (1987:16) assumes that the mother and daughter kept watch for some length of time and tended to the baby's needs until deciding on the right time for the launch; he even posits that the ark was relocated for safety and feeding purposes.

15 Durham (1987:16) agrees that there is no textual suggestion that the ark carrying its baby cargo was deliberately placed where a sympathetic woman could find it. Durham believes that discovery by an Egyptian would put the baby immediately in harm's way.

16 Examples are Ebed Melech who confronted King Zedekiah in public in such a way as to force him to release Jeremiah from the cistern (Jer. 38:1-13); Joseph who knew how to run a household to please his master, Potiphar (Gen. 39:6); Harbona, a eunuch attending Xerxes/Ahasverus, king of Persia, who told the king of Haman's plot to hang Mordecai (Est. 7:9); and the servant girl of Naaman's wife who knew that Elisha could cure her master of leprosy (2 Kings 5:3). 
the mother and young daughter knew the habits and character of the princess and planned their actions accordingly. 17

Consider this key text: Exodus 2:6, "She opened it and saw the baby. He was crying and she felt sorry for him. This is one of the Hebrew babies," she said (italics added). Arguably, the mother and daughter knew of the princess's compassion; potentially they knew or surmised she longed for a child. Several possibilities arise: Perhaps the princess has a reputation for compassion and fair dealing.18 Perhaps she has a reputation for making her own independent decisions. Perhaps the mother and sister know her character to be one that would disagree with Pharaoh's edict of genocide. Perhaps they knew her to be a woman of courage and fairness, one capable of making decisions.

The encounter between Miriam and the princess sparkles with shrewdness (Durham, 1987:16). ${ }^{19}$ The situation presents the princess with an immediate conflict.20 With the discovery of the ark and its baby, the princess faces the choice of obeying her father - and ordering an Egyptian soldier to kill the Hebrew baby - or disobeying him and sparing the life of a child the text describes as beautiful (Ex. 2:2).

Miriam gives the princess a moment to work through her emotions. Then Miriam, prompt and bold, steps forward. Remember, she is a slave, and a child. Circumventing all attendants, she addresses the princess directly. "Shall I go and get one of the Hebrew women to nurse the baby for you?" (Ex. 2:7) (italics added).

A skilful persuader listens. Notice how Miriam uses the same key word Hebrew - that the princess used. Repetition shows someone is listening.

17 Another in the biblical text who knew the habits of a regent was Hegai, the eunuch in charge of the harem of Xerxes/Ahasverus. Hegai noticed Esther immediately and provided her with beauty treatments, special food, and seven maids to wait on her; he moved her into the best section of the palace (Est. 2:8-9). The text strongly indicates by this special notice that he wanted her to win the beauty contest and to win the crown.

18 The daughter of Pharaoh traditionally is Tharmuth (Jub. 47:5) or Bithia (B.Meg. 74, 91; B.Ber. 41) (Hyatt, 1971:64). The only ones named in Exodus 1 and 2 are the midwives, Shiphrah and Puah (their names respectively mean "beauty" or "fair one" and "splendour" or "splendid one" - Hyatt, 1971:60-61 - and Moses.

19 Durham (1987:16) adds, "The suspense of the discovery is that it was unintended and dangerous. The delight of the discovery is the totally unexpected way it turned out. The climax of the discovery is the quick and bold action of the little boy's sister, who comes forward (with a convenient offer to find a wet nurse) when she sees the princess's reaction to her brother's tears." 
Miriam definitely listens intently. Repetition shows courtesy, for it utilizes language already on the table, so to speak. Repetition shows empathy, for it uses a word someone already is comfortable with.21

With this statement - "Shall I go and get one of the Hebrew women to nurse the baby for you?" (Ex. 2:7) - Miriam makes several amazing mental jumps. She assumes the princess wants the child, although the princess has not said anything of the sort. Possibly, she assumes the following:

- The princess will go against her father's decree

- The princess will not order the child to be killed

- The princess will face her father's wrath to save the child

- The princess chooses to put her life in jeopardy to save this child

- The princess wants this child for her own

Miriam's question also provides a way out for the princess. The princess is faced with a decision about what to do. This decision takes place in a public setting with her attendants and guards watching. Palace gossip, being what it is, means that her decision will become palace knowledge within moments.

Each character in this vignette, the princess and the girl, thinks quickly. The girl's timely question buys the princess time. It gives the princess a chance to delay ordering or sanctioning the killing of the baby. The girl immediately returns with the baby's mother. Meanwhile, it would seem that a plan forms quickly in the mind of the princess. She will take the child once it is weaned. Again, her action buys time for herself to figure out her options and to ensure the child's life. An interesting sidenote is that the princess is honourable in her dealings: although the employer and negotiator, she makes it clear she pays for services rendered in her employ. The princess' shrewdness likewise becomes apparent: she refrains from saying how much the wages will be. Quite likely different wages were paid to her different employees and she did not want them comparing amounts.

In her interaction with the princess, Miriam uses two persuasive techniques: incentives and empathy.22 Miriam offers the princess the incentive to become a mother. The interesting twist in this case is that an

21 A repetitious word also signals the reader to pay attention (see Alter, 1981:95).

22 See Eales-White (1997:41-45) for a thorough discussion of incentives and empathy. 
incentive most often comes from a superior like an employer rather than from a subordinate like a child and slave.

Miriam also employs another persuasive technique called empathy. A possible reading of the princess' exclamation, "This is one of the Hebrew babies" (Ex. 2:6), is longing. Perhaps there is a longing in her voice for a child. Perhaps there is compassion in her voice for a doomed, helpless infant. Perhaps there is outrage in her voice over the arbitrary injustice of murder ordered by her father. The text remains silent, as is its usual case, on the thoughts and feelings of individuals. But the actions and words of the princess show she desires the child to live and refuses to be part of its destruction. 23

The person employing empathy skilfully deflects attention away from herself (Eales-White, 1997:42). Miriam does this. Yet while focusing her attention on the needs of the infant and the assumed needs of the princess, Miriam remains aware of her goal and purpose - namely to save her baby brother's life. Consequently, she remains very much the one in control of the situation. Her question ("Shall I go and get one of the Hebrew women to nurse the baby for you? (Ex. 2:7)) performs two functions: it keeps the focus on the crying child, the helpless child, and it forces the princess to make a decision. Obviously, the child needs to be fed!

Miriam so cleverly employs empathy that she pulls the persuadee, the princess, toward her own viewpoint (Eales-White, 1997:42). Her question employs one of the strongest uses of empathy: Miriam in effect says to the princess, "May I help you?" (see Eales-White, 1997:43). Her actions and question also seem to say, "I would value your opinion on this: Don't you think the baby needs a wet nurse immediately?" (see Eales-White, 1997:43). 24

A persuasion style that stresses empathy immediately enables people to make friends. It instantly recognizes how important the other person is, the one to be persuaded (Eales-White, 1997:43). It creates bonds. Indeed, a lifelong relationship develops between this Hebrew family and Pharaoh's daughter.

23 For an excellent discussion on the role of character in narration see Kaiser and Silva (1994:67-84).

24 Language is so important in an empathetic persuasive approach. Other questions or statements in this approach could include the following: I trust your judgement. How do you feel about this? I understand your position; now let me explain mine. I agree. My goodness; that must have been a terrible disappointment for you. Please give me your opinion on this. l'd like to hear your ideas. (See Eales-White, 1997:43.) 
A persuasion style using empathy points out that someone, the persuader, recognizes a deep need in another person. Miriam does this. The deep need in the princess is not named. Possibly, because of the focus of Exodus 1, it could be a sense of outrage against her father for his decree of genocide. Possibly it could be the need or desire to be a mother; the text gives no indication of the princess' marital status. An indication is given, because she is surrounded with serving maids, that she herself is single, young, and of marriageable age. Perhaps her need could be only this: That she as a princess needs to make an immediate decision as to whether or not to follow Pharaoh's order to kill the male Hebrew babies. This could be her immediate need. Whatever the need of this unnamed royal woman, Miriam's question - "Shall I go and get one of the Hebrew women to nurse the baby for you?" - meets it. What is important is that Miriam intuitively understands the conflict the baby's finding presents to the princess. Miriam does not necessarily know what the princess's needs are. What is important is that Miriam offers a way out.

The princess accepts Miriam's way out. It buys her time. It saves face her face and status and reputation among her serving girls. It meets the baby's immediate needs (nobody enjoys hearing a crying child!). It saves a life and forestalls an immediate killing. Significantly, the text remains silent about how the princess tells Pharaoh about her new adopted son and about his reaction to her deed.25

Other textual silences also are important. Look what Miriam, an able communicator, wisely avoids. First, Miriam avoids long, complicated questions. She asks one question. She avoids making the princess choose between Hebrew women or between an Egyptian and a Hebrew woman; in other words, Miriam avoids "either/or"-questions. Second, she presents one option (that of getting one of the Hebrew women to nurse the child), the option most favourable to Miriam and her mother. Third, she skirts entirely guilt-laden questions like: "Surely you don't want to see an innocent baby killed," and: "Shouldn't you take the baby in?"

The empathy style of persuasion uses/employs mutual respect. The persuader, in this case Miriam, asserts herself honestly and forthrightly to someone she regards as a person of dignity. The response from the persuadee, in this case the princess, is returned respect. Miriam per-

25 The biblical text remains silent about the housing arrangements the princess and the wet nurse/mother arrange. Hyatt (1971:64) speculates that the Mesopotamian practice is followed, namely that the wet nurse takes the child to her own home, receives her wages for her services, and then delivers the child, once weaned, to her employer; the employer then adopts the child. 
suades the princess that it is in her - that is, the princess's - best interest to save the baby's life. The princess grabs the chance offered her. 26

\section{Abigail}

The rabbis commend Abigail, a very assertive woman, on two accounts and rebuke her on one. First, they include her as a prophetess. ${ }^{27}$ Second, they say she ranks as one of four women of surpassing beauty. 28 Third, they rebuke her for flirting with David. From the start, her beauty puts her at an advantage. In addition, the biblical text itself heaps accolades on her: she is the only woman in scripture called both intelligent and beautiful (1 Sam. 25:3). With biblical compliments like these, the text immediately establishes her as a formidable, accomplished woman, clearly a woman of stature.29 Read another way, David does not have a chance! 30

Here's the story. Circumstances catch Abigail in the middle between two men, one selfish and stupid and the other violent. Her husband Nabal foolishly refuses to share festival provisions with David and his men; and David, feeling publicly slighted in front of his men, foolishly vows to avenge himself by slaughtering all the males in Nabal's household by morning. ${ }^{31}$

26 The princess later continues the God-given role of bestowing a name (see Gen. 1; $2: 19 ; 3: 20)$. While the name Moses may have a Hebrew etymology meaning "to draw out", it also could be a form of "to be born". There are similarities with the names of pharaohs like Thut-mose, which means "The god Thut is born" (Hyatt, 1971:65).

27 See footnote 3.

28 The other three are Sarah, Rahab, and Esther (Megillah 15a) (Encyclopedia Judaica, 1971:vol. 2, 73-74).

29 After her husband has died, she is referred to via the epithet, "widow of Nabal" (Shearing, 1992:15).

30 In an interesting article, Adele Berlin (1983:30-33) writes that each interaction with a woman corresponds to a period in David's public life. Here, in his interaction with Abigail, his gentlemanly response and chivalry toward her once she is a widow display him as a self-assured, popular leader.

311 Samuel 25 portrays an aspect of David heretofore not seen: David is violent toward a fellow Israelite, one who in all probability is a distant relative. Readers of the text are accustomed to David's nobility of character. 1 Samuel 25 comes between two instances when David chooses not to kill Saul. In the first inclusio instance, he and his men hide in a cave; Saul comes in to relieve himself, and David clips a portion of his robe as evidence of his ability to have slain the king (1 Sam. 24). In the second inclusio, David spares Saul's life on the hill of Hakilah facing Jerusalem (1 Sam. 26). 
Here's her predicament. When told by a servant of Nabal's offending words against David, her actions indicate she realizes immediately that David will come himself with the sword.32 Her life and those of her household stand in jeopardy. In order to save her household, she immediately countermands the wishes of her husband. By her actions, namely her commands to her servants to load up a princely feast, she chooses the immediate well-being of her household. The bounteous provision represents an outright bribe to appease David. $\mathbf{3 3}$

Abigail begins her counter attack on David by using one of her greatest assets: her body. She employs astute body language. She dismounts from her donkey as soon as she and David seem to collide head on in a mountain ravine. She bows down, her face touching the ground, and she conducts her speech at his feet - seemingly looking up at him (1 Sam. 25:23-24). The text indicates she recites her long speech - 153 words from this very servile and uncomfortable position!34

She begins in a most attractive and appealing way: with humility. She quickly and voluntarily humbles herself in front of someone her husband shortly before had debased as a break-away slave (1 Sam. 25:10). Abigail readily assumes responsibility and blame for Nabal's actions. An immediate response from a hearer like David quite likely is, "But it is not

The text also gives numerous other instances in which Saul tries to kill David, but David refuses to try to kill Saul.

32 Brueggemann (1990:175) says Nabal is not so much a bad man as a stupid man. But the text fails to back this up. Nabal is more a man self-absorbed in his possessions, for he is defined by them and is self-absorbed in his own private drinking parties. Bergen (1996:245) notes that Nabal was intellectually and/or ethically foolish. He comes, however, from an influential family and could boast of both Caleb, the faithful spy, and Othniel, a mighty judge, as prominent ancestors. And most certainly he was one of David's kinsmen (Bergen, 1996:246).

33 The text presents Abigail as a woman who prepares in advance for difficulties her household may face. The text indicates she quickly organizes a sizeable gift of food for David and his men. Yes, this is an appeasement offering. The text says, "Abigail lost no time. She took two hundred loaves of bread, two skins of wine, five dressed sheep, five seahs of roasted grain, a hundred cakes of raisins, and two hundred cakes of pressed figs, and loaded them on donkeys" (1 Sam. 25:18-19). Truly a banquet! Klein (1983:249) notes the intended pun on wine skins (nabali) and Nabal.

34 Abigail's astute body language forces David to be noble. It is against his manhood as well as the rules of chivalry of all ages to slay an unarmed woman (and a beautiful one bearing gifts at that!) who humbles herself at his feet. Her humility honours him publicly in front of her servants and his men. 
your fault. You didn't even know about it!" This opening manoeuvre on Abigail's part buys her time and gives her an advantage. 35

The biblical text gives no indication that David and Abigail have met beforehand. Nevertheless, Abigail apparently knows of him by reputation. Skilful persuaders study their subject - even from afar. She knows well the stories about this man who already is a legend in his own lifetime. Unlike Miriam, Abigail does not have time to listen. Unlike Miriam, Abigail refrains from asking questions; she bypasses them and makes assumptions based on common knowledge about David. She combines this knowledge with feminine intuition.

Eales-White's fourth model (1997:45), group, proves useful in evaluating Abigail's persuasive conversation. Abigail addresses David as a group, in other words, in his multiple capacities. She addresses him in his roles. In her speech, the longest by a woman in the biblical text, ${ }^{36}$ she addresses aspects of his life. These aspects include one who is an outlaw; one who is a wronged protector; one who is responsible for the lives and livelihood of the outlaws under him; one who knows the Lord; one who is known to fight the Lord's battles; one who has enemies; one who is a hero in Israel; one who is too noble of character to slay innocent people; one who is the rightful king now; one who will be king; and one who, as a man, is very, very susceptible to the well-chosen words of a humble, beautiful, desperate woman. In her own very persuasive way, Abigail launches a counter attack on multiple levels. ${ }^{37}$

The group model Abigail employs bombards David with concepts, ideas, dreams, and visions (Eales-White, 1997:45). She begins by acknowledging him as another wronged by Nabal and one justified in his feelings of outrage (1 Sam. 25:24). In this way, she recognizes the vengeful part of his character - yes, she acknowledges its existence. But her speech uses the other parts of his character - the hero, the godly man, the covenant man, the leader of men, the noble king, and the man who certainly will be king - to override or gang up, so to speak, on the

35 By taking the responsibility for her husband's churlish actions, Abigail effectively offers herself as a martyr on behalf of her husband and household (see Bergen, 1996:250). Yet again as in her opening action of falling at his feet, her humility and assumption of the blame are consistent. These actions endear her favourably toward those present, as well as to subsequent readers and hearers. These actions give her an extended audience with David. By her actions, she has earned the right to continue speaking.

36 Her speech contains 153 Hebrew words. The prayer of Solomon (1 Kings 8:15-22) contains 121 words, and the prayer of Daniel (Dan. 9:1-19) contains 264 words.

37 Abigail's speech is one of the most remarkable female-initiated encounters in the biblical text (Bergen, 1996:249). 
side that seeks revenge. She reminds him of the part of the law that says, "It is mine to avenge; I will repay" (Deut. 32:35).

She also uses empathy. Abigail and David share a common enemy: Nabal. She knows how he feels to be wronged by Nabal. 38 After all, she as his wife is wronged by him every day; she knows him for who he is wicked, a fool, and full of folly (1 Sam. 25:25). Although she knows David rightfully wants to avenge himself for the slight Nabal gave him, she encourages David not to avenge himself at all but instead to let the Lord avenge him. The implication is that she lets the Lord avenge her for the many slights in this unequal marriage as well. By using this technique, she creates empathy (see Eales-White, 1997:46). She establishes a bond with David. They unite in attitude against Nabal - her husband.

Her speech contains the skilful use of an inclusio: she begins by saying that the Lord has kept David from needless bloodshed (the killing of her household) and ends with saying that during David's rightful reign, he will not have the staggering burden of needless bloodshed (the killing of her household) on his conscience (1 Sam. 25:26, 31). The use of the inclusio as bookends shows that Abigail never loses sight of her purpose - to save her household.

The text indicates that quite possibly she prophesies several times. First, she prophesies that the Lord has kept David from bloodshed. Next, she prophesies that David's life is surely and securely bound up in the bundle of the living 39 and that David's enemies - especially King Saul - will be hurled out like a stone from a sling. She wants David's enemies dead (Klein, 1983:250-251). And finally she prophesies that the Lord will do for David many good things (1 Sam. 25:26, 30).40

As a wordsmith, she matches David skill for skill. For example, she uses key words from his past famous battle with Goliath - hurl and sling (1 Sam. 25:29). She calls herself David's handmaid or servant six times; she mentions the Lord eight times, and calls David her lord 14 times (1 Sam. 25:23-31).41 Is she obsequious? Maybe so - but the technique

38 Abigail also is viewed as shrewd rather than as good; likewise, Nabal is viewed as unwise rather than as evil (Shearing, 1992:15).

Klein (1983:251) notes that this is a synonym for the book of life.

40 Sadly in later life, David will not always be kept. No Abigail restrains his passion when he rapes Bathsheba (2 Sam. 11).

41 There is some discussion that the difference between servant sph and servant 'amh; possibly it is a distinction between a servant who works in the household and a servant of marriageable position. For example in Ruth 3:9, which takes place at the threshing floor, and in which Ruth asks Boaz to fulfil his duties as kinsman redeemer and marry 
works on David. Her speech flatters him, honours him in a public way, and via her words she flirts with him in a feminine, public way that compliments his masculinity. Note that my lord also can be translated as my husband. $\mathbf{4 2}$

Actually, Abigail persuades via deliberate provocation. She uses the weapons available to her: her femininity, her quick thinking, her common covenant in the Lord with David, her knowledge of the nobler side of his character, her beauty, her vulnerability, her use of words, her humble position at his feet.

And what man can resist a beautiful woman? A woman who compliments him? A woman who falls defenceless at his feet? A woman who builds him up before his men? A woman who knows his reputation? A woman whose eyes and speech show she admires him? A woman who arouses him sexually because of her beauty, wisdom, generosity, defencelessness, and her open enjoyment of him as a man? Certainly not David. $\mathbf{4 3}$

Abigail ends her appeal with a command: Remember me, your handmaid (1 Sam. 25:31). What might this mean? Remember me tonight when I have to face Nabal? Remember me in my difficult marriage to our common enemy? Remember me for good when you are acknowledged as king? Remember that your handmaid has called you my lord, my husband, six times? Remember me with kindness because I have saved you from shedding unnecessary blood? Remember that I have called

her, Ruth uses the 'amh version, which may indicate she is a servant whom Boaz can consider marrying; in the earlier scene in the field (Ruth 2:13), she is a sph, a servant. Abigail, on the other hand, immediately uses the 'amh version and only once in the middle of her speech (1 Sam. 25:27) reverts to what may be the "lesser" designation for servant, sph. Abigail ends strongly on 'amh: (1 Sam. 25:31b): "And when the Lord has brought my master success, remember your servant ('amh)."

42 The narrator indicates she and David would make a good match because they share characteristics: each is in covenant with the God of Israel; each enjoys a fine vocabulary; each commands servants; each enjoys the respect of servants; each is physically quite attractive. Regarding the latter, the same Hebrew word for beautiful (yph) describes David and Abigail (1 Sam. 16:12); the same is true of noble character (hayil) for Boaz and Ruth (Ruth 2:1; 3:11). Similarly, yph describes both Joseph and his mother Rachel, a word choice leading scholars to to speculate that they looked alike.

43 David is not immune to her beauty, but it is "her good understanding, her shrewd common sense, and her cunning way with words that make a crucial difference in the narrative" and equally important, a crucial difference in David's life (Brueggemann, 1990: 176). 
you king? Remember that I have indicated in words and deeds that I want you to marry me?44

Her brilliant appeal to David in his many roles is logical, intuitive, empathetic, and very, very feminine. ${ }^{45}$ She talks to David on various levels of his personality; she brings up his past; she knows he will have a future; she reminds him of his close relationship with the Lord. She shows that she, at least, thinks about his legacy. By honouring him, she saves her household.46 She taps into David's dreams when her speech indicates she knows he will be king. In doing such, she compliments David and shows that she shares his vision. $\mathbf{4 7}$

David responds with characteristic praise to God. He immediately sees God's hand in her intervention.48 The text does not say how Abigail gets up from the ground; possibly David leans down and helps her rise with his hand. Perhaps he cups her face with his hands. The scene is one of the most romantic in the biblical text. The Hebrew expression which is translated in English "I have granted your request" (1 Sam. 25:34),

44 Abigail, the most assertive of the three characters in this paper, models these aspects of assertiveness (see Eales-White, 1997:114). She respects herself and others namely her servants. She respects what David has done - a protection scheme for her husband's livestock. She does not respect foolish actions, namely her husband's refusal to allow David and his men to come to a sheepshearing party. She admits she is culpable; she takes upon herself the mistakes of her husband. She expresses her views openly. She listens to her servants and expects to be immediately obeyed; likewise, she expects David to listen to her. She says exactly what she thinks and feels in language that is assertive, winsome, wise, gracious, and to the point. In this fight for her life and the life of her household, she leads, and she leads courageously. She is the real leader of her household because her servants trust her.

45 Via Abigail's persuasive communication, she successfully accomplishes three things: she intercedes on behalf of her husband, herself, and her household; she prophetically reveals David's destiny as the founder of a dynasty and vanquisher of the Lord's enemies; and she prevents David from shedding innocent blood out of pique and thereby usurping the Lord's right to avenge and judge (see Bergen, 1996:249).

46 Commentators universally praise Abigail. For example, Blaikie (s.a.:99) says, "With the quickness and instinctive certainty of a clever woman's judgment, Abigail, Nabal's wife, saw at once how things were going. With more than the calmness and self-possession of many a clever woman, she arranged and despatched the remedy almost instantaneously after the infliction of the wrong ... Her promptness and her prudence all must admire, her commissariat skill was wonderful in its way; and the exquisite tact and cleverness with which she showed and checked the intended crime of David - all the while seeming to pay him a compliment - could not have been surpassed."

47 Dreams and visions, Eales-White (1997:116-122) indicates, tap into the creativity parts of our psyche and brain.

48 It is the mark of sincere and genuine godliness to be not less thankful for being kept from sinning than from being rescued from suffering (Blaikie, s.a.:99). 
literally means, "I have raised/lifted up your face". In effect, David blesses her three times. He blesses the Lord who sent her; he blesses her discretion, and he blesses her (1 Sam. 25:32-33) (Brueggemann, 1990:180). An interesting characteristic of David emerges during this encounter: David listens. He really listens to Abigail. With the ready instinct of a gracious heart he recognizes Abigail's interruption of his plans as the providential hand of God (Blaikie, s.a.:99).

\section{The Wise Woman of Abel Beth Maacah}

The Wise Woman of Abel Beth Maacah joins Miriam and Abigail as one who uses words wisely. She remains anonymous in the biblical text (2 Sam. 20:16-22), defined only by her status and function (wise) and by her gender (woman) and by her location (Abel Beth Maacah).49 The rabbis, however, fill in details about her. They say she is Serah, the stepdaughter of Asher who was raised in the household of Jacob.50 The biblical text mentions Serah three times in genealogies as the daughter of Asher,51 a textual fact showing her significance, but contains no stories or elaboration about her. The rabbis, however, say "she walked in the way of pious children, and God gave her beauty, wisdom, and sagacity" (Ginzberg, 1968:2:39). She also escapes the "kiss of death" and ranks as one of those who does not die. 52

The Wise Woman of Abel Beth Maacah makes a cameo appearance in the biblical text during a time when Israel faces a calamity. Civil war threatens to topple the throne of David. Sheba, a Benjamite, mounts an

49 Keil and Delitzsch (1872:455) note that Abel Beth Maacah in the late 1800s was a large Christian village called Abil-el-Kamh; it enjoyed a reputation for excellent wheat; it lies to the northwest of Lake Hulah on the eastern side of the river Derdara.

50 For an excellent discussion of Serah, see Leila Leah Bronner's article (2000:187-198), "Serah and the Exodus: A Midrashic Miracle."

51 Genesis 46:17; Numbers 26:46; and 1 Chronicles 7:30.

52 Others include Enoch and Elijah and Ahijah; the biblical text substantiates the continued life (or at least the escape from death) of Enoch and Elijah, and Jewish tradition claims the same for the prophet Ahijah. According to another Jewish legend, when Joseph's brothers returned from Egypt and had to tell their father that Joseph lived, they asked Serah, by now a beautiful maiden, to play on the harp and to sing the news that Joseph lived to the elderly Jacob. She sang, "Joseph, my uncle, liveth; he ruleth over the whole of Egypt; he is not dead!" (Ginzberg, 1968:2:115). Jewish tradition says that as she played, Jacob believed, and the spirit of prophecy, which never visits except when a seer is in a state of joy, again visited him. Jacob rewarded her with these words, "My daughter, may death never have power over thee, for thou didst revive my spirit!" (Ginzberg, 1968:2:116). Jewish tradition maintains Serah escaped death, served her people as the Wise Woman of Abel Beth Maacah, and entered Paradise alive (Ginzberg, 1968:2:116). 
insurrection. Shortly beforehand, David had fired Joab, commander of the Israelite army, replacing him with Amasa. David now orders Amasa to muster Israel's forces against Sheba. But Amasa dallies and fails. In a ruse of brotherhood, Joab calls Amasa over and murders him. Then Joab seizes command of the army of Israel. Joab pursues Sheba to Abel Beth Maacah, a fortified town in northern Israel.

The city of Abel Beth Maacah now faces a predicament: Joab's siege. Someone - singularly described only as a wise woman - becomes the city's spokesperson. She calls to Joab from the wall. She asks why he attacks a peaceful city known in Israel as a seat of wisdom. He replies that Sheba has "lifted up his hand against the king, against David" (2 Sam. 20:21).

During the dialogue, control of the situation and the siege switches from Joab with his army and its weapons of war to a woman with her weapons of common sense and insightful words. Joab wants Sheba. The Wise Woman promises even more: Joab will have his head! She retreats from the wall and counsels the townspeople; their conversation, however, remains unrecorded by the narrator. Evidently they agree with her for after cutting off Sheba's head, they toss it over the wall. The army disperses. The Wise Woman's actions - although awful for Sheba - quell further community bloodshed and stop the fratricide of Israelite killing Israelite - at least temporarily. Although refraining from comment, the narrator regards her counsel and actions highly because he introduces her as wise. The chapter ends with a named list of David's male officials (2 Sam. 20:23-26); significantly, the list begins with Joab, commander of Israel's army.

In this vignette the Wise Woman of Abel Beth Maacah quickly and artfully employs persuasive logic. She begins her counter attack with several advantages. The first is logistical: she calls out from atop the city wall, forcing all who reply to her to look up.53 The second is her anonymity; never in the dialogue with Joab does she reveal her name; she, however, knows to summon the one in charge, Joab, commander of the army of Israel. Third, she begins with a distinctly religious word said twice: "Shimu! Shimu!" "Listen! Listen!" 54 In only seven verses (2 Sam. 22:16-22) the Wise Woman employs logic as her primary persuasive

53 "The introduction of direct discourse, a new character, the change of perspective from besiegers to besieged all signal the beginning of a new event," writes Geyer (1987:36). "Fortunately, the effect of the woman's cry on the attackers is to check their frenzied advance, to make them stop and listen."

54 The "Shema", probably the most well-known creed in Israel, starts with the same verb, smy, (Deut. 6:4). 
technique. 55 She quickly deploys a barrage of wordy weapons including four commands, two questions, one proverb, an accusation, and a promise. Her efforts end successfully: the army spares the city.

Eales-White (1997:35) describes logic as the heart of language and hence the heart of communication. Typical language phrases or nuances in logic as a persuasive technique include an assumption like this: You cannot do whatever you want to do because it is illogical (Eales-White, 1997:36). This is essentially the Wise Woman's argument. Another language phrase in the logical approach is this: The facts speak for themselves (Eales-White, 1997:36). The Wise Woman employs facts in her use of questions, assertion, and promise. Essentially the Wise Woman argues that besieging Abel Beth Maacah represents a stupid action because Joab besieges a recognized national treasure and a city that is an inheritance from the Lord. And Joab is not stupid.56 In the logical mode, the persuader presents facts; the persuadee, in this case Joab, agrees to the facts because he understands the logic that leads to the conclusion (Eales-White, 1997:37)

As backup reinforcements, the Wise Woman secondarily uses two other approaches: the incentives and empathy modes of persuasion. Via the incentives approach, she promises Joab Sheba's head in exchange for his promise to leave Abel Beth Maacah. Via the empathy approach, she agrees with Joab that the rebel Sheba represents an enemy of the state.

A careful reading of the interaction between Joab and the Wise Woman shows she employs an astute strategy and remains the one in control of the situation. She begins by shouting to all below in the process of building siegeworks to listen. She then requests to talk to Joab. She takes her time in her interchange with him. $\mathbf{5 7}$ She delays in stating her purpose at first. When he stands below her at the wall, she begins with a question: "Are you Joab?" The question shows she wants to talk only to the man in charge. The question says she and all Israel know Joab because of his military prowess and reputation. The specific summons of

55 Truly these seven verses prove pivotal, for the political destiny of a nation changes because of them.

56 The biblical text presents abundant evidence of Joab's military expertise, his courage in battle, his ability to command and lead men for decades, his brilliance in strategy, and his loyalty to David and David's house. Significantly, however, Joab never casts a covetous eye toward the throne.

57 The Wise Woman's speech certainly has a poetic quality, Anderson notes (1989:241). The essence of the Wise Woman's argument seems to be that the people of Abel Beth Maacah are people of good sense. Yet the text leaves unexplained why they have good sense. After all, they do not start negotiations prior to the siege. 
Joab by name and then the specific question publicly flatter the commander. After the question, she commands again a third time. "Listen to your maidservant's complaint."

She humbles herself by calling herself a maidservant, more specifically, Joab's handmaid ('amh) (2 Sam. 20:17). But she is not a maidservant; she is a leader. Actually, the term your handmaid ('amh) should have alerted Joab that something momentous was about to happen. Whenever a woman uses the term your handmaid ('amh) in the biblical text, the tables turn on the man in charge, and the man in charge loses the verbal confrontation. In his verbal exchange with the Wise Woman of Abel Beth Maacah, Joab agrees to play along and appears to know the verbal game itself. 58 Joab replies to the woman on the wall, "I am listening" (2 Sam. 20:17). 59

58 This is because of an earlier exchange with the Wise Woman of Tekoa (see 2 Sam. 14).

592 Samuel supports the view that servant and maidservant are terms loosely spoken by confident and powerful men and women respectively when they seek to use their influence among themselves. Joab used this technique of overstated humbling of himself when he wanted to get Absalom back from exile. Joab falls on his face before David and says, "Today your servant knows that he has found favour in your eyes" (2 Sam. 14:22).

A number of women in 1 and 2 Samuel and 1 and 2 Kings use the term handmaid, including Hannah, Abigail, the witch/medium of Endor, Tamar, the wise woman of Tekoa, the wife of Elisha's friend the prophet, the queen of Sheba, the widow of Zarephath, the "good" prostitute, the Shunammite, the Israelite girl who became the servant of Naaman's wife, and now the Wise Woman of Abel Beth Maacah. The term signals women who use their subservience to get what they want. As an appositive of self-description of choice, it occurs 22 times in the Hebrew Bible. While not manipulators, these women yet play their roles well and achieve their purposes.

The term handmaid shows deference and humility. But the words of the handmaid invariably are forceful, specific, and self-assertive. While veiled in deference, the words of a handmaid reveal a fine mind, critical thinking skills, and deference to the Lord.

Farmer (1998:928) points out that commentators like Jack M. Sasson, Edward F. Campbell, and Illona Rashkow believe that 'amh, handmaid, carries a higher status than does sph, servant and is the more familiar, more intimate term of the two.

In contrast, the narrator uses the term shiftah, bondslave, to describe Hagar, Zilpah, and Bilhah (Gen. 16:1, 25; 29:24, 29; 30:4; 35:25, 26). Some texts show a progression and interchange of the terms servant and handmaid when applied to a woman. For example, when Boaz first speaks to Ruth, she answers using the term bondslave; but when she meets him at the threshing floor, she calls herself his handmaid and asks him to spread his mantle - symbolic of his name and marriage and protection - over her. Clearly the reticent bondslave at the beginning of the barley harvest became the bold handmaid at the end of the wheat harvest. Ruth's use of 'amh, handmaid, in her dialogue with Boaz in the threshing room makes her "eligible for marriage with her master", Farmer (1998:928) argues (Ruth 3:9). While the purpose of the Wise Woman of Abel Beth Maacah obviously is not marriage to Joab, her choice of the word 'amh, 
The Wise Woman talks to Joab in three terse sentences. She begins with what seems to be part of a proverb: "Long ago they used to say, 'Get you answer at Abel,' and that settled it" (2 Sam. 20:18).60 Gordon (1986:296) believes the Wise Woman of Abel Beth Maacah quotes a proverb in proof of the city's well-known reputation for wisdom and good counsel. She speaks as a leader of a city famous in Israel and as its honoured representative. 61

The Wise Woman's proverb reminds Joab of a long-standing tradition in Israel, namely that Abel Beth Maacah carries the reputation of being a seat of justice.62 The text lets stand the view that it enjoys national goodwill as a city for settling disputes, as a city known for its arbitration skills, and as a city that seeks peace between brothers in Israel. In

handmaid, suggests a recognition on her part of his fame throughout Israel and an equality with him. See footnote 40 .

Similarly, in the back-and-forth verbal parry between David and the Wise Woman of Tekoa, the woman begins by calling herself his slave and then switches to handmaid midway through the chapter when she asks the king to perform the request of his handmaid (2 Sam. 14:6, 15). But she reverts to the more formal and subservient bondslave in her last words to David when he discovers the hand of Joab has guided their interchange (2 Sam. 14:19).

Similarly, the widow of Elisha's friend the prophet and the Shunammite (2 Kings 4) choose to use the word bondslave perhaps because they realize their predicaments need a miracle. The widow's sons face slavery to pay for their father's debts. Without a miracle the Shunammite faces the stigma of childlessness.

Likewise, when Eli encourages Hannah to go in peace and prays that the God of Israel grant her request, she answers with graciousness, humbling herself. She says, "May your bondslave find favour in your eyes" (1 Sam. 1:18). The prostitute who wanted her son to live called herself Solomon's handmaid (1 Kings 3:20).

Clearly, the women who call themselves handmaids, servants, and bondslaves and men who call themselves servants form a special class of people in Deuteronomistic literature.

60 The woman uses a proverb which the text appears to recount only partially (Hertzberg, 1964:373).

61 Geyer (1987:37) sees a history of judicial proceedings at Abel Beth Maacah. She believes the city may have been a seat for second trials, where verdicts were reexamined under a change of venue. This city clearly was known for its administration of justice, for its expert verification of testimony, for its ability to settle disputes (Geyer, 1987:37). See footnote 63.

62 The Wise Woman calls her city a mother city; as such, it potentially has daughter cities, satellite cities. The use of the term mother bears examination. Mothers are honoured equally with fathers in the sixth commandment (Ex. 20:12). Women as mothers are seen as protectors; Psalm 57:1 talks of a hen protecting her chicks, and Psalm 61:4 speaks of the shelter wings provide. In the ANE, a mother city meant a tribal designation in the early traditions of the Hebrews (Gen. 25:16; Num. 25:15); a metropolis in Phoenicia; a kinship term in Ugaritic; and a military unit in old Babylon (McCarter, 1984:430). 
2 Samuel 20, however, the city graduates from settling disputes between individuals to settling disputes between the house of David and Sheba, a Benjamite. In addition, it suddenly becomes a centre for a dispute itself. $63 \mathrm{~A}$ town known as a peacemaker within a province or area for so long is too valuable to all Israel to be wiped out, the Wise Woman tells Joab (Dean, 1955:361). Her double use of the word Israel indicates her loyalty to her country (2 Sam. 20:19). Her allegiance transcends the tribes of Benjamin or Judah. She and her city remain true to a cause larger than tribalism: they stand neutrally for all Israel, as a national seat of wisdom. In her next sentence, she purposefully equates herself with Deborah, a mother in Israel, by calling her city a mother in Israel, a metropolis (Gordon, 1986:296). This phrase, "a mother in Israel", is used only twice in the Hebrew scriptures (2 Sam. 20:19; Judges 5:7).64 The phrase raises problems for scholars, for they admit the original readers and hearers knew a context now lost to modern ears.65 Similarities dominate over differences in the contexts of the two usages. Both phrases are spoken by women; Deborah refers to herself, and the Wise Woman refers to her city - or possibly to herself. 66 Both contexts show favour and a good report.

Both phrases employ the mother image; they purposefully connote a place of honour. They indirectly bring up the sixth commandment, the first one with a promise attached to it: Honour your father and your mother that your days may be long in the land the Lord is giving you (Ex. 20:12). The context in both phrases spoken by the two women is extreme need. In Deborah's time, Israel needed a deliverer from the

63 Abel Beth Maacah's location merits scrutiny. The fact that it is in the outer reaches of the kingdom suggests Sheba's exhaustion, his plan to seek refuge in a desperate attempt to save his life, and his loss of hope after Joab's pursuit.

64 The obscure term has few commentators. See J. Cheryl Exum's article (1986:60-67) on mothers in Israel who built up the house of Israel through their own resourcefulness and the fame of their sons.

65 Keil and Delitzsch (1872:455-456) note that the woman speaks in the name of the city. They pick up on her concern for the city's heritage as a recognized place of wisdom and on her concern for the city's inhabitants. Keil and Delitzsch (1872:456) view the phrase "mother in Israel" as jargon for the capital of an area; they (Keil \& Delitzsch, 1872:455) believe Abel Beth Maacah is celebrated and widely known for the wisdom of its inhabitants.

66 If she refers to herself, she purposefully equates herself as a judge in Israel, a woman carrying on the tradition of Deborah. This raises the interesting possibility of a tradition of female judges in Israel up through the monarchy of David. 
Canaanites. 67 Deborah and the Wise Woman rise up as the deliverers of a nation and of a city. 68

In both, the phrase "a mother in Israel" signals a turn of action. It causes Joab to swear an oath, explain his position, and offer a plan (2 Sam. 20:20-21). In Deborah's Song, it operates in a priestly position separating a theophany about God's prowess and introducing the tribes that acted as his agents in the war - or did not.

The Wise Woman's question - would Joab destroy a mother in Israel and swallow up the Lord's inheritance? - begs a negative reply. She apparently compliments Joab on his intelligence and then questions it. How could someone with Joab's intelligence and record wish to level a city so long beloved in Israel? Naturally, she seems to say, it would be stupid to acerbate tensions in Israel by destroying so renowned a national treasure. And as stated earlier, the text presents Joab as one of the moste intelligent and influential man in the kingdom.

Most scholars concentrate on the phrase "mother in Israel" but gloss over the city's other appositive, "inheritance of the Lord". 69 This implied meaning is contained in the Wise Woman's third sentence, a question, to Joab, "Why do you want to swallow up the Lord's inheritance?" (2 Sam. 20:18). The Deuteronomistic writer or writers, however, employ this phrase a number of times. The Wise Woman's use of the word in-

67 Deborah sings that village life ceased, ceased "until I, Deborah, arose, arose a mother in Israel!" (Judges 5:7).

68 Both phrases touch on death. Deborah the judge and military leader faces death at the hands of the Canaanites. The Wise Woman faces death from Joab's army. The words "a mother in Israel" directly affect their hearers. All Israel recognizes Deborah as a judge for all Israel, not just a judge for her region, Ephraim. The Wise Woman probably speaks loudly enough so that the citizens of Abel Beth Maacah and the army of Israel on the other side of the wall both can hear her. The use of the phrase unifies Israel each time. The phrase seeks to alleviate any form of pitting tribe against tribe. Both phrases contain the possibility of rebuke. Deborah in her role as mother in Israel rebukes the rich who ride donkeys and the tribes and clans of Reuben, Gilead, Dan, and Asher for not following the other Israelites (notably Zebulon and Nephtali) in the holy war against the Canaanites (Judges 5:5, 15-17). Similarly, the Wise Woman rebukes Joab for trying to destroy a city that is a mother in Israel, one known as the Lord's inheritance (2 Sam. 20:19).

69 The key phrase, "swallow up the heritage of the Lord", may mean that the people of Abel held an inalienable title to their land, an action in accordance with the tradition of Yahweh's allocations to the tribes during the settlement period (see Lev. 25:23, 28; Num. 27:1-11; 36:7-9; 1 Kings 21:3 f) (Gordon, 1986:296). 
heritance seems to refer to the people of Israel themselves (see 1 Sam. 10:1).70

Chapter 20, however, opens with a negative emphasis on the word inheritance, for Sheba's rally cry is, "We have no inheritance in David!" (2 Sam. 20:1). But in general, inheritance is considered something good in the Hebrew Bible. For example, all Israel is the inheritance of God (Ps. 78:71). 71

By skilfully identifying herself with the city, with Deborah the great judge, and with a good gift from the Lord, the woman puts Joab in a difficult position in a public setting. She continues her logical persuasion by appealing to Joab's stature in Israel and to his honour as an Israelite. She states she is the one who is the peacemaker, the one who is faithful in Israel. Her logic invites him to join her as a peacemaker and one who is faithful in Israel. The woman also appeals to Joab's sense of manhood. Her words imply that when he strikes Abel Beth Maacah, he strikes her - and striking a woman and killing her is beneath his manhood as an Israelite.

Her words, which began as a compliment, end as an indictment. 72 She calls Joab forth, lays a charge upon him, and convicts him.73 The judgement seems to leave Joab dumbfounded. The biblical texts about Joab recount nobody except the king ever spoke to him in this way. ${ }^{74}$

Via her request from the wall to talk to Joab, then her command to him to hear, and then with three rapid sentences which follow, the Wise Woman seizes control of the situation. She talks like a prophet. She quickly turns the verbal tables on Joab. Showing her skill at reasonable discourse, she quells for a moment the battering ram against her city's gate.75

70 Inheritance comes up five times in 1 and 2 Samuel (1 Sam. 26:19; 2 Sam. 14:16; 20:1, 19, 21:3).

71 Other instances of inheritance include these: God gave the land of Israel to the tribes as their inheritance (see Joshua 19); the boundary lines have fallen for me in pleasant places; surely I have a delightful inheritance (Ps. 16:6).

72 Perhaps for this reason, Hertzberg (1964:373) describes Joab's encounter with the Wise Woman of Abel Beth Maacah as delightful.

73 With the present altercation at her gates, she displays her ability to prosecute. Therefore, because of her skills, the woman's indictment of Joab rings true because she is the one qualified to judge (Geyer, 1987:38).

74 See 2 Samuel 3:28-32, David's stinging indictment of Joab's slaying of Abner.

75 As in many sombre situations in the Hebrew Bible, the story being told in 2 Samuel 20 contains some humour. For example, her words wryly remind Joab that his methods of 
The Wise Woman's words show her devotion to the Lord. She claims the city as an inheritance of the Lord and appears amazed that Joab even entertains a thought of exterminating it. She argues against a herem, a wholesale slaughter of inhabitants and a burning of the city. ${ }^{76}$

In the verbal parley with Joab, she maintains the advantage of the one asking rapid-fire questions; by doing so, she becomes the one in charge. She remains a woman of mystery because she does not reveal her name. This shows her wise strategy. Her anonymity gives her the upper hand in the verbal game. In the story so far, Joab has been the attacker with weapons. Suddenly the unnamed woman now attacks with words. In less than a minute, she reverses the siege. Joab responds with the oath, "Far be it, far be it from me". $77 \mathrm{He}$ acts thoroughly befuddled.

Although the woman on the wall mildly rebukes Joab, she wisely avoids arousing his anger. Her question rebukes him for not following the law of Moses. She apparently assumes Joab undoubtedly already knows the good reputation of the city and the propensity of its inhabitants toward wisdom and peace. Deuteronomy 20:10 says, "When you as an invader march up to attack a city, makes its people an offer of peace." Holy war against such a city, an innocent city, the woman reasons, represents an error.78 Joab returns the woman's rebuke with a mild oath, "Far be it from me"; a modern translation is, "It is not as you say."79

battering ram and siege ramp are not the usual ways one seeks counsel at Abel Beth Maacah. Is it not more reasonable to ask first than to batter?

76 See Deuteronomy 3 for a list of cities where herem occurred.

77 The phrase "Far be it from me" (2 Sam. 20:20) and its slight variations occur six times in 1 and 2 Samuel and once in Job. Joab says it twice in this verse alone to the Wise Woman of Abel Beth Maacah. Four times it is spoken by man, once by God, and never by a woman. Part of its significance may be that it is an oath spoken only by men; women in biblical literature employ a milder oath. For example, Ruth says to Naomi, "May the Lord deal ever so severely with me" (Ruth 1:17).

78 Dean sympathizes with the inhabitants of Abel Beth Maacah. "The people," she (Dean, 1955:361) writes, "were in such a plight, the innocent victims of one man who had sought refuge inside their walls and had brought an avenging army knocking at their gates."

79 Levine writes on Numbers 30:2-17, a section on voluntary oaths. He (Levine, 1999:84) finds that a voluntary vow was a traditional practice among the Israelites. From his reading of the biblical text, he notes that it becomes clear that men and women make voluntary vows during events in their lives so that they can remember them during upcoming circumstances and do them.

Although Levine's article covers only Numbers 30 , it suggests a tradition in Israel that carried beyond the time in the wilderness. Joab's voluntary oath to the Wise Woman of Abel Beth Maacah binds him to wanting only Sheba. By not destroying the city, Joab keeps his oath. 
Her sound reasoning makes Joab pause. Although he fails to apologize for his assault, he explains he pursues Sheba, one who "has lifted up his hand against the king, against David" (2 Sam. 20:21). By saying "against the king, against David" Joab lets the Wise Woman and the city know of the defeat of Absalom's rebellion; he informs them that David still reigns. His stress on the king and David shows the turmoil of the country. Exactly who, after all, is king? David? Absalom? Mephibosheth? Another? Rumours run rampant when a country faces the turmoil of civil war. Joab clarifies who reigns. By naming David as king, he in effect asks if the city is loyal to David or is part of the insurrection? He volunteers to withdraw from the city if the city hands over one man, Sheba. 80

The Wise Woman makes a quick, logical, executive decision. She agrees to do as Joab asks. However, she retains overall control by saying the city will do more than Joab requests: its inhabitants will send Sheba's head over the wall. By convincing the city to execute Sheba, she shows Joab - and ultimately David- the city's loyalty to David. Furthermore, the glory of the battle and the credit for quelling the rebellion ultimately go to the Wise Woman and to the city - and not to Joab.81

Throughout the verbal exchange, the woman acts as an executive. She negotiates as an equal (or even as a superior) directly with another leader. She promises something; then she goes back to her constituents and convinces them to deliver it. Her past with them gives her standing for her argument to prevail. She acts as judge, counsellor, prosecutor, and leader.82

80 Cryer (1985:389) believes Joab graciously accedes to the request of the Wise Woman of Abel Beth Maacah to withdraw. Furthermore, Cryer believes the text presents a favourable picture of Joab.

81 In this she also resembles Deborah, for the credit for Deborah's War goes to Deborah and Jael, not to Barak (Judges 4:9; 5:24, 27, 31).

82 The narrator of 2 Samuel 20 remains silent regarding the words of the Wise Woman's talk with her townspeople. But evidently Sheba garners no support from them for his life. Joab's threat (backed by his army) remains clear: sacrifice the town for one man, or let that one man pay for his own rebellion against David. The woman's view (evidently echoed by the city) that in this case it is better that one should die so that many should not perish prevails. A millennium later Caiaphas, the high priest in Jerusalem during Jesus' time, also used this reasoning in deciding to seek the execution of Jesus (see John 11:50). That Sheba sought, without much success, to overthrow the kingdom undoubtedly added to the strength of her argument. The narrator calls him a worthless fellow, a troublemaker, a fool (2 Sam. 20:1). The text clearly presents him as an unattractive character, one without much charisma (unlike David and Joab), one who could not muster forces for a rebellion against the king. The 
Her swift reversal of roles via words from the one besieged to the one who judges comes as a surprise to the reader and to Joab. It represents the turning point in the confrontation, for it quells two rebellions: Sheba's insurrection and Joab's siege that pits Israelite against Israelite (see Geyer, 1987:38).

She deftly manoeuvres Joab both to deny his wrong doing and by denying it to change his actions. "Why are you swallowing up an inheritance of Yahweh?" she asks. Joab must deny such a charge - to do otherwise admits he fights against the Lord. The woman throughout this conversation exhibits the confidence of one who rationally and routinely exercises authority. The woman personifies the city. Her words indicate that Joab, in attacking the city, attacks her and God. The woman's attack suddenly becomes personal and theological. She denounces Joab's attempt to attack her and her city and to kill its inhabitants. The woman wisely brings in a moral element in her argument: this city is sacred; it is an inheritance of Yahweh. When Joab fights against Abel Beth Maacah, he fights against Yahweh.83

\section{Conclusion}

This article has examined the persuasive communication techniques used with great skill by two women and a little girl. Each figures as a political saviour in the history of Israel. Each acts quickly during a crisis that threatens the lives and destiny of God's covenant people. In addition to Miriam, Abigail, and the Wise Woman of Abel Beth Maacah, other political saviours in the biblical text who happen to be women include Deborah, Esther, and Rahab.

Women who win with words and act as political saviours share the following characteristics:

- They act, often on a large scale, for the good of their family, community, or the nation

text gives no mention of any who rallied to his battle cry; quite possibly none came to the sound of his trumpet. In contrast, when Joab blows the trumpet (2 Sam. 20:22), many men obey; they disband, heeding the order to go home, and shed no more blood. The woman's public speech and her private communication with her townspeople show her high standing in the city. She is accustomed to listening, to defending, to seeking answers, and to being an arbitrator.

83 Abigail used a similar argument with David (see 1 Sam. 25). Just as she prevented David with her wise counsel from slaying innocent blood in her compound, the Wise Woman of Abel Beth Maacah prevents Joab with her argument from slaying innocent blood by overwhelming the city. 
- Against armed might, they skilfully use as weapons their wit, femininity, and words

- They study the one with whom they interact

- They listen intently

- They use key words

- They ask relevant questions

- They offer a way out of a crisis

- They refrain from heaping guilt upon others

- They seek to preserve life but are not averse to shedding blood

- They judge between the righteous and the unrighteous and side with the righteous

- They make life-and-death decisions and participate in their implementation

- The narrative presents them favourably

- The narrative backs up their judgments

- They serve as examples in the biblical text to other women and to men by offering an alternative in words and wise counsel to violence

\section{Bibliography}

ALTER, R. 1981. The art of Biblical narrative. New York : Basic Books.

ANDERSON, A.A. 1989. 2 Samuel. Waco, TX : Word.

BABYLONIAN TALMUD. 1939. Baba Bathra. Megillah. Sanhedrin. Ed., Rabbi Dr. I. Epstein. Jerusalem : Soncino.

BERGEN, R.D. 1996. 1, 2 Samuel. Nashville, Tennessee : Broadman \& Holman.

BERLIN, A. 1983. Poetics and interpretation of Biblical narrative. Bible and Literature Series 9. Sheffield: Sheffield Academic Press.

BLAIKIE, W.G. s.a. The Second Book of Samuel. Ed., W.R. Nicoll. The expositor's Bible. Vol. 2. 1 Samuel - Job. New York : Doran. p. 113-212.

BRONNER, L.L. 2000. Serah and the exodus: A midrashic miracle. Exodus to Deuteronomy: A feminist companion to the Bible. (Second Series.) Ed., Athalya Brenner. Sheffield: Sheffield Academic Press. p. 187-198.

BRUEGGEMANN, W. 1990. First and Second Samuel. Louisville, Kentucky : John Knox Press.

CALVIN, J. 1852. Commentaries on the four last Books of Moses arranged in the form of a harmony. Vol. 1. Edinburgh : Calvin Translation Society.

CHADWICK, G.A. s.a. The Book of Exodus. Ed. W.R. Nicoll. The expositor's Bible. Vol. 1. Genesis - Ruth. New York : George Doran. p. 117-232.

CHILDS, B.S. 1974. The Book of Exodus: A critical, theological commentary. Philadelphia : Westminster. 
CRYER, F.H. 1985. David's rise to power and the death of Abner: Analysis of 1 Sam. 26:14-16 and its retaliation and critical implications. Vetus Testamentum, 35:385-394.

DEAN, E. 1955. All the women of the Bible. Edison, New Jersey : Castle Books.

DURHAM, J.I. 1987. Exodus. Waco, Texas : Word Books.

EALES-WHITE, R. 1997. The power of persuasion: Improving your performance and leadership skills. London : Kogan Page.

ENCYCLOPEDIA JUDAICA. 1971. 16 vols. Jerusalem : Keter.

EXUM, J.C. 1986. The mothers of Israel: The patriarchal narratives from a feminist perspective. Bible Review, (2):60-67.

FARMER, K.R. 1998. Ruth. Ed., Leander E. Keck. The Interpreter's Bible: A commentary in twelve volumes. Vol. 2. Numbers, Deuteronomy. Introduction to narrative literature. Joshua. Judges. Ruth. 1 \& 2 Samuel. Nashville: Abingdon. p. 890-946.

FRETHEIM, T.E. 1991. Exodus. Louisville, Kentucky : John Knox.

GEYER, M.L. 1987. Stopping the Juggernaut: A close reading of 2 Samuel 20:13-22. Union Seminary Quarterly Review, 41:33-42.

GINZBERG, L. 1968. Legends of the Jews. 6 vols. London : Soncino.

GORDON, R.P. 1986. I \& II Samuel. Grand Rapids : Regency, Zondervan.

HERTZBERG, H.W. 1964. I \& II Samuel. Philadelphia : Westminster.

HYATT, J.P. 1971. Exodus. London : Oliphants.

KAISER, W.C. \& SILVA, M. 1994. An introduction to Biblical hermeneutics: The search for meaning. Grand Rapids, Michigan : Zondervan.

KEIL, C.F. \& DELITZSCH, F. 1872. The Books of Samuel. Edinburgh : Clark.

KLEIN, R.W. 1983. 1 Samuel. Waco, Texas : Word Publishers.

KRAMER, P.S. 2000. Miriam. Ed. Athalya Brenner. Exodus to Deuteronomy: A feminist companion to the Bible. [Second Series.] Sheffield, England : Sheffield Academic Press. p. 104-133.

LEVINE, B.A. 1999. Vows, oaths, and binding agreements: The section on vows in light of Aramaic inscriptions. Eretz-Israel, 26:84-90. Jerusalem : Israel Exploration Society.

LOSTRACCO, J. \& WILKERSON, G. 1998. Analyzing short stories. Dubuque, lowa : Kendall/Hunt.

MCCARTER, P.K., Jr. 1984. I and II Samuel: A new translation with introduction, notes \& commentary. Garden City, New York : Doubleday.

NEW INTERNATIONAL VERSION. 1995. Grand Rapids, Michigan : Zondervan.

RAPPOPORT, A.S. 1966. Myth and legend in ancient Israel. 3 vols. New York: KTAV Publishing House.

SHEARING, L.S. 1992. Abigail. New York: Doubleday.

\section{Key concepts:}

Abigail

Miriam

persuasive communication

Wise Woman of Abel Beth Maacah, the

women in the Old Testament 
Kernbegrippe:

Abigajil

oorredingskommunikasie

vroue in die Ou Testament

wyse vrou van Abel-Bet-Maäka, die 